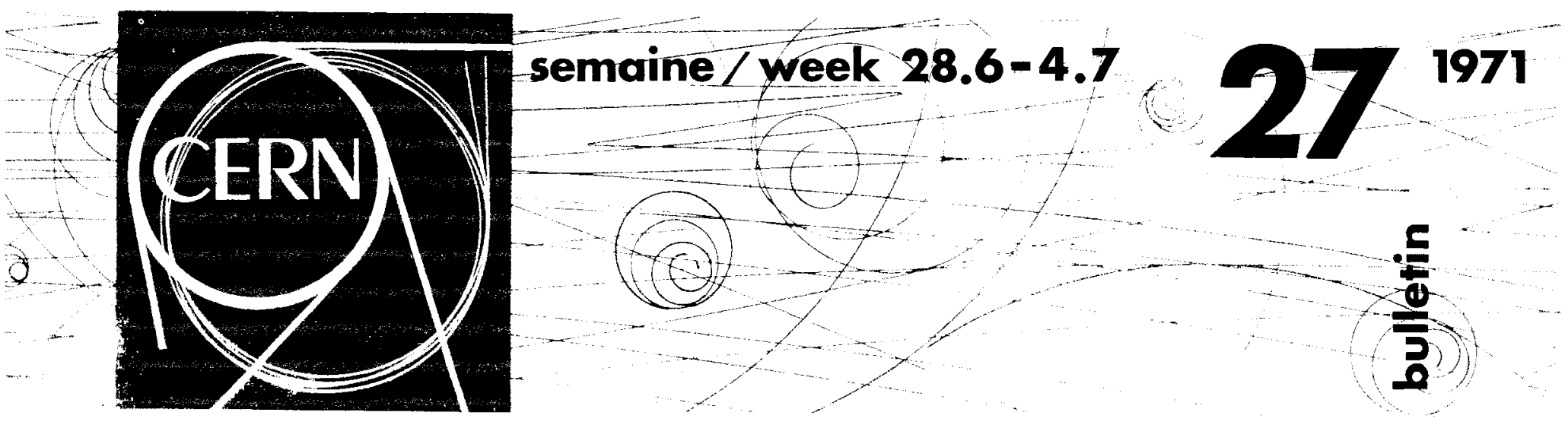

\title{
FUTURE TECHNICAL DEVELOPMENTS
}

Last Tuesday the Auditorium was crowded with scientists from inside and outside CERN listening to and discussing an overall review of future technical developments. Three sessions were dedicated respectively to the 'machines' (PS \& ISR), to the particle detectors and to data acquisition and analysis. During the course of the day many novel ideas were presented by experts in the various fields and the audience was probably too intent on absorbing these interesting facts to engage in the animated and far-reaching discussion which had been hoped for, particularly in view of the presence of so many people from outside laboratories. With regard to the PS, which, after all, forms the basis of so much of the research facilities, an important subject was the new systems of proton distribution to the various users whose interests are often conflicting. Many difficulties will have to be overcome owing to the new tasks of the PS as an injector for both the ISR and, eventually, the SPS and the problems caused by the greater beam intensities : the possibility of accelerating deuterons and polarized particles as well as even more exotic particles. It has also to be borne in mind that this is a machine that was commissioned in 1959 with a control system that has evolved but is still, in essentials, the same as was conceived in those distant days of the middle fifties.

\section{DEVELOPPEMENTS TECHNIOUES FUTURS}

Mardi passé l'amphithéâtre regorgeait de scientifiques du CERN et de l'extérieur, rassemblés pour une revue générale des futurs développements techniques. On y discuta "machines" (PS \& ISR), détecteurs de particules, recueil et analyse de données. La journée vit présenter nombre d'idées nouvelles par des experts de diverses disciplines qui ne rencontrèrent guère dans l'assistance toutle potentiel de discussions espéré.

Au sujet du PSqui, après tout, constitue la base de tant d'installations expérimentales, il fut question de nouvelles méthodes de répartition des protons entre les divers utilisateurs dont les besoins sont souvent divergents. Beaucoup de difficultés devront être résolues tant en raison de l'affectation du PS à l'injection des ISR et, plus tard du SPS, qu'aux problèmes dus à une plus grande intensité, ou qu'à la possibilité d'accélérer deutérons, particules polarisées ou corpuscules plus exotiques encore'. Dans ce contexte, il faut aussi considérerque le PS a été mis en route en 1959 avec un système de commande modifié depuis, certes, mais demeuré essentiellement le même qu'en ce bon vieux temps. 